\title{
Mesenteric paraganglioma's: an important differential diagnosis in intra-abdominal tumours
}

\author{
Nebu C Jacob, ${ }^{1}$ Mark Howard, ${ }^{2}$ Mark Kelly, ${ }^{1}$ Peter C Hale \\ ${ }^{1}$ Department of Digestive Diseases, Brighton and Sussex University Hospitals, Brighton, UK \\ ${ }^{2}$ Department of Histopathology, Brighton and Sussex University Hospitals, Brighton, UK
}

Correspondence toDr Nebu Chacko Jacob, nebujacob@yahoo.com

\section{DESCRIPTION}

We present the case of a 63-year-old lady who complained of feeling constantly tired and lethargic, and was found to have iron deficiency anaemia. There was no history of per vaginal bleeding. Examination was normal apart from a large, mobile, firm, well-defined abdominal mass in the upper abdomen approximately $10 \mathrm{~cm}$ in diameter. The abdominal CT scan revealed a large intra-abdominal tumour (figure 1). Histology of the specimen obtained by surgical resection revealed this to be a mesenteric paraganglioma (figure 2). To the best of our knowledge, there are eight other reported cases of mesenteric paraganglioma's. Ninety per cent of these sympathetic tissue tumours arise from the adrenals and are called phaeochromocytomas. Paraganglioma's are extra-adrenal phaeochromocytoma's, of which $85 \%$ arise in the abdomen, $12 \%$ in the thorax and the remaining $3 \%$ in the head and neck. ${ }^{1}$ Paraganglioma's that hypersecrete catecholamines may cause signs and symptoms identical to those in patients with hyperfunctioning adrenal pheochromocytoma. Recent studies implicate genetic factors in up to $25 \%$ of cases. The most frequent causes of phaeochromocytoma susceptibility are von Hippel-Lindau disease, multiple endocrine neoplasia type 2 , and the newly delineated phaeochromocytoma-paraganglioma syndrome.

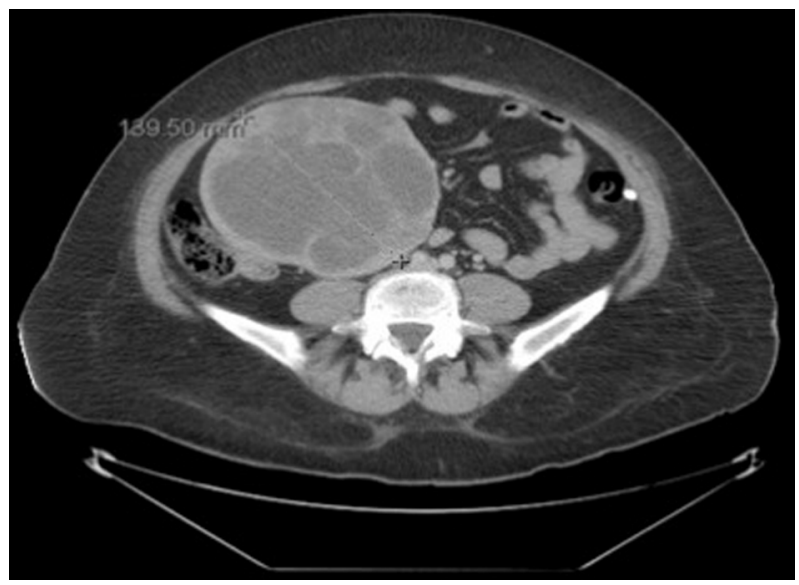

Figure 1 CT scan of the abdomen with intravenous contrast showed a $139 \times 125 \mathrm{~mm}$ well-circumscribed mixed cystic/solid mass arising within the peritoneal cavity, to the right of the midline, displacing bowel loops. Posteriorly it was closely related to the inferior vena cave and anterior margin of the right psoas.

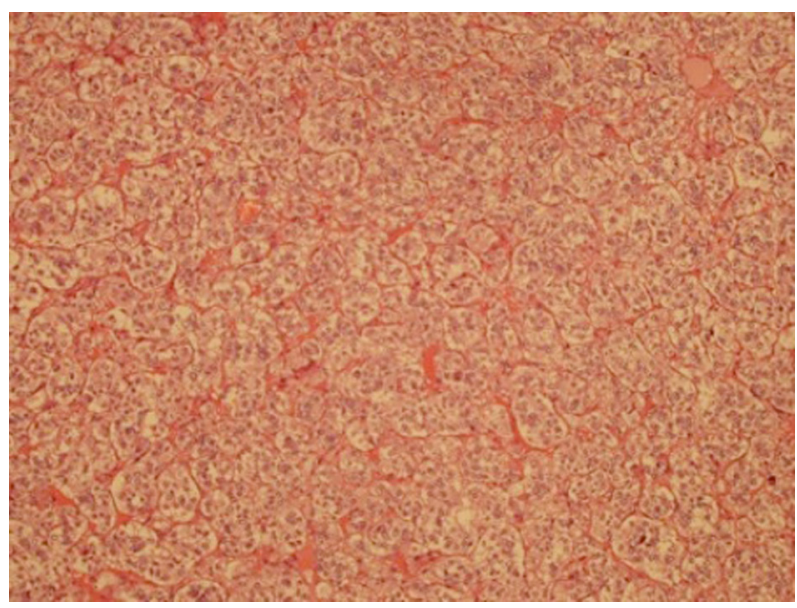

Figure 2 Classic nesting pattern (Zellballen) of paraganglioma H\&E staining, 100X magnification.

Germline mutations in three of the succinate dehydrogenase subunits (SDHD, SDHB and SDHC) increase susceptibility to head and neck paragangliomas, and familial and isolated phaeochromocytomas. ${ }^{2}$ Differentiation between benign and malignant forms is difficult by imaging alone. There are no definite documented criteria for classification as a malignant form apart from the presence of distant metastases, which must be proven with biopsy, because paragangliomas may exhibit multicentricity. ${ }^{3}$

\section{Learning points}

- Keep in mind the possible differential diagnoses at all times, as even specialised imaging such as contrast CT scans may not always provide the answer.

- Excision of paraganglioma's is the treatment of choice after optimisation of the patient. Formal follow-up protocol, however, is yet to be established in view of the limited number of cases.

- Genetic testing should be considered in all patients presenting with paraganglioma's.

Competing interests None

Patient consent Obtained. 


\section{BMJ Case Reports}

\section{REFERENCES}

1. Myssiorek D. Head and neck paragangliomas: an overview. Otolaryngol Clin North Am 2001;34:829-36, v.

2. Maher ER, Eng C. The pressure rises: update on the genetics of phaeochromocytoma. Hum Mol Genet 2002;11:2347-54.
3. Elder EE, Xu D, Höög A, et al. KI-67 AND hTERT expression can aid in the distinction between malignant and benign pheochromocytoma and paraganglioma. Mod Pathol 2003;16:246-55.

This pdf has been created automatically from the final edited text and images.

Copyright 2012 BMJ Publishing Group. All rights reserved. For permission to reuse any of this content visit http://group.bmj.com/group/rights-licensing/permissions.

BMJ Case Report Fellows may re-use this article for personal use and teaching without any further permission.

Please cite this article as follows (you will need to access the article online to obtain the date of publication).

Jacob NC, Howard M, Kelly M, Hale P. Mesenteric paraganglioma's: an important differential diagnosis in intra-abdominal tumours. BMJ Case Reports 2012;10.1136/bcr.02.2012.5726, Published XXX

Become a Fellow of BMJ Case Reports today and you can:

- Submit as many cases as you like

- Enjoy fast sympathetic peer review and rapid publication of accepted articles

- Access all the published articles

- Re-use any of the published material for personal use and teaching without further permission

For information on Institutional Fellowships contact consortiasales@bmjgroup.com

Visit casereports.bmj.com for more articles like this and to become a Fellow

Keep up to date with all published cases by signing up for an alert (all we need is your email address) http://casereports.bmj.com/cgi/alerts/etoc 